\title{
After the Wildfires: The Processes of Social Learning of Forest Owners' Associations in Central Catalonia, Spain
}

\author{
Roser Rodríguez-Carreras ${ }^{1}$, Xavier Úbeda ${ }^{1}$, Marcos Francos ${ }^{2, *}$ (i) and Claudia Marco ${ }^{1}$ \\ 1 Department of Geography, Faculty of Geography and History, University de Barcelona, Montalegre, 6, \\ 08001 Barcelona, Spain; roserodriguez@ub.edu (R.R.-C.); xubeda@ub.edu (X.Ú.); \\ claudiamarco@ub.edu (C.M.) \\ 2 Departamento de Ciencias Históricas y Geográficas, Universidad de Tarapacá, 18 de Septiembre, 2222, \\ Arica 1000000, Chile \\ * Correspondence: marcosfrancos91@gmail.com; Tel.: +56-9-4277-4326
}

Received: 24 June 2020; Accepted: 25 July 2020; Published: 28 July 2020

\begin{abstract}
Over the last few decades, according to the Forest Fire Prevention Services of the Catalan Government, a small number of fires (less than 1\%) have been responsible for the destruction of more than three quarters of the burnt forest area in Catalonia. However, while these wildfires have transformed many components of the landscape, including its vegetation and soils, they offer landowners the opportunity to learn from past decisions. This article aims to analyze the responses of forest owners in Central Catalonia after the great forest fires of the 1980s and 1990s, including the way in which their objectives and strategies are defined and their actions implemented. By conducting interviews with the members of forest owners' associations and by means of participant observation at association meetings, we seek to examine the processes of social learning experienced by this collective and to identify the mechanisms used in their efforts to create socio-ecological structures that are less vulnerable to fire. Associationism is unusual in the world of Catalan forest ownership, despite the great number of private forest areas. In our results, however, associationism emerges as a strategy for cooperation, a recognition of the need to link ecological and social structures in the territory, and one which we define as a form of 'socio-ecological resistance'. Our study highlights that the goals and actions of forest owners' associations have both an instrumental and emotional component, so that reason, emotion and action have come to form the three vertices of socio-ecological resistance to fire.
\end{abstract}

Keywords: large wildfires; forest management; forest owners' associations; social learning; resistant socio-ecological structure

\section{Introduction}

Fire, a natural element, with a presence dating back millions of years, is known to have played a significant role in the shaping of Mediterranean landscapes [1-4]. Likewise, fire has also been adopted as a tool for the management of these ecosystems, humanized since time immemorial $[5,6]$. Furthermore, other human activities, and especially those affecting land use and land management changes, have a huge influence on fuel availability and its structure, two characteristics that have played a major role in modulating fire regimes across the Mediterranean Basin [4,7]. Interestingly, a number of recent studies call into question the effects of an increase in the frequency, intensity and scale of fires and their relationship with extreme episodes of heat and drought induced by climate change [8,9]. Yet, changes in fire regimes appear to be affecting all Mediterranean climate zones around the world, including those of Portugal [10], Spain [11], Greece [12], Israel [13,14] and Chile [15]. 
In Catalonia, according to fire data issued by the Catalan Government (the Generalitat) for the period 1986 to $2017,12 \%$ of fires (excluding fires affecting areas $<1$ ha) burnt areas greater than 500 ha, accounting for $83 \%$ of the surface burned annually [16].

Against this backdrop, and considering that EU forest lands are gradually increasing, it is important to observe the responses of stakeholders and forest owners to the social and landscape transformations to which rural and forest areas are exposed [17-19] as well as their responses to wildfires [20-22]. In particular, we need to understand the specific motivations of, and the strategies employed by, forest owners to manage their properties $[23,24]$ as it is related to social perceptions of wildfire risk [25-27], and to be dependent on the information owners have about this risk [28-30]. The organizational responses of forest owners have been found to influence political decision-making [31], whilst information exchange between social agents is reported to help build a sense of community [32]. It should be stressed from the outset that EU forests account for $42 \%$ of the Union's total land area, and that $60 \%$ of this area is privately owned [33]. In Catalonia, where forests account for $64 \%$ of the total land area, $76 \%$ is privately owned. In Central Catalonia, however, the percentage under private ownership ascends to $94 \%$ [34].

The social impact of fire is multidimensional, with economic, political, cultural and ecological consequences [35-37]. This makes the integral assessment of its effects a complex task [38-40]. To direct and indirect economic losses, we need to add the ecological and landscape losses, and we cannot ignore the emotional impact the wildfire had on those directly affected $[38,41]$. However, in the face of the uncertainty and complexity of current socio-ecological processes, those involved in the management of social-ecological systems have the capacity to learn [42-44] and to implement concerted actions [45]. A process of social learning [44,46-52]-the taking, that is, of collective action in the management of social ecological systems-is essential in order to develop and enhance an adaptive capacity [42] to pro-environmental attitudes $[53,54]$. The outcomes of this learning should, in turn, contribute to creating a socio-ecological structure-as a part of a fundamental change in attitudes, behaviors and social norms $[44,55,56]$ — that is, one that is less vulnerable to wildfires and which can coexist with fire as a natural element $[57,58]$.

The social-ecological structure aims a) at tying the needs of the ecological structures with those of the prevailing social structures of a territory $[49,59]$, so as to achieve stable lifestyles and settlements firmly grounded in that territory, while redefining the relationship between the forest landscape and its management within the organizational social structure; and b) at preventing or reducing the impact of large wildfires, whilst at the same time recognizing that it is impossible to eliminate them altogether from Mediterranean ecosystems, hence the need to learn to live with them [60,61]. Individuals and groups, by means of their collective efforts, can influence the adoption of social actions that affect the course and quality of their lives [46,62-65]. Collective actions, and their subsequent impact on learning processes, occur when individuals and groups seek to improve the management of socio-ecological systems [49] as the set of regular interactions between social and biophysical factors that create the rules and resources organized by society, the social environment and nature [42]. Hence, the theory of social capital [66-68] is applicable here for evaluating the role that organizational networks (as part of a collective action) can potentially play in natural resource management [67] and planning [69-71] at the local and regional scales.

Forest owners' associations and coordinated forestry in Catalonia are still at an incipient stage [72] but studies of cooperation among forest owners are increasing [73-84]. A study was even undertaken of forest owners' associations in Catalonia by Navascués and Llobet [85]. Despite this, few studies focus specifically on the subject of social learning among forest owners after a wildfire and on the associated socio-ecological processes. In this study, we seek to fill this gap in the research.

\section{Objectives, Hypotheses and Theoretical Framework}

This study examines the response of forest owners to the wildfires of Central Catalonia in the 1980s and 1990s and the owners' processes of social learning. More specifically, the study focuses 
its attention on the forest owners' associations of Berguedà Verd and Boscos Bages-Anoia, located in the comarcas (i.e., local administrative divisions) of Berguedà, Bages and Anoia, as well as on the associations of Bages-Vallès and Entorns de Montserrat (located in Bages, Baix Llobregat and Vallès Occidental). The associations are organizations in which the interests of both private property and public administration are represented. The hypotheses we seek to test are that (1) a process of social learning occurs after large wildfires and (2) forest owners' associations exemplify both a rational and emotional strategy for achieving objectives and defining actions in what might be described as a scenario of social and ecological resistance following a wildfire.

One of the first authors to lay the theoretical groundwork for understanding social learning was Albert Bandura [46], who highlighted the mutual relationship between our experiences (cognitive learning) and our observations of other people in a given normative setting (social context). A number of recent theoretical contributions to the concept turn the spotlight on three principal dimensions, considered central to any analysis of social learning: First, the depth of learning, that is, changes in understanding, attitudes and behaviour; second, the collective character of learning, facilitated by processes of social interaction, and, third, the internalization of this learning by broad segments of society [49,50,52,56,86-89]. Reed et al. [49] consider social learning to involve a change of understanding within wider social units or communities of practice and going from superficial to deeper levels, entailing a change in attitudes, world views or epistemological beliefs. Authors such as Mezirow [88] and Sharpe [56], who link social learning with transformative learning, argue that this change is related to the ability to move from a critical examination of experience to action and, so, to question the unsustainable practices associated with a greater community exposure to risk and to embrace resilience [56] and creativity processes [90].

Dedeurwaerdere [52] considers social learning as the recourse to criteria of sustainability as an open-ended device that can be implemented through actions and from which new forms of social cooperation can be built. This is made possible by creating suitable conditions for linking experiences, reflection, and experimentation between individuals and groups [86,91,92]. According to Sempere et al. [48] and Rist et al. [51], social learning is strongly related to the intensity of public debate, understood not as a simple negotiation between private interests, but as a deliberate process (arranging rules, norms and power relations) to ensure that the general interest emerges in the management of natural resources and in the relations between humanity and nature.

To evaluate the actions that the forest owners' associations take, Weber's concept of social action is useful [62]. A social action is one in which the subjective meaning takes account of the behavior of others, beyond the sum of individual decisions, or the imitation of patterns of behavior. Weber classifies social actions into four types: rational-zweckrational instruments which are oriented towards obtaining results; wertrational, those that have value (ethical, moral) in their own right, independent of their results; traditional responses, those that depend on established conventions; and reactive-emotional responses. Weber considers these categories to be pure, but, in practice, actions comprise elements of all these categories. Similarly, González-Hidalgo and Zografos [63] recognize the importance of taking into account the emotional dimension when it comes to studying the processes of forming resistance and the constructs of political subjects in environmental struggles. For this reason, here, we examine the presence and absence of rational, traditional and emotional responses generated in the wake of major episodes of wildfire.

We refer to social-ecological resistance as a collective indicator based on a redefinition of the relationship between society and forest spaces via the process of learning. In terms of fire ecology and forest management, resistance to fire is the ability to modify the behavior of the fire by employing techniques of forestry intervention in certain strategic locations with the purpose of reducing the number of large wildfires and, in this way, avoiding traumatic economic and ecological losses [16]. Resilience, on the other hand, is the ability of an ecosystem to recover and develop structures and systemic processes similar to those that existed before the fire [16,93]. 
But these changes take place in a social context. We hypothesize that it is necessary to promote not only ecological resistance but also social resistance to large wildfires. This procedure aims to build new forms of interaction and coexistence between forest owners and the rural world and their surroundings and the disturbances. We consider forest owners' associations to be a form of overt resistance [94]. According to the classification offered by Hollander and Einwohner [95], that is an organized collective action aimed at creating spaces of socialization of practices and discourse, publicly recognized, with political intentionality (i.e., the type of resistance identified by Richardson and Johanningmeir [16]). We define the socio-ecological structure in a social-ecological system [96] as the relationship between social (organization of the rural world and forest owners to generate spaces of empowerment and a collective discourse [94]) and biophysical factors (forestry intervention in strategic locations at the landscape scale) to create landscape structures and landscape-scale management that takes into account forest fires with the aim to reduce fire severity and fire intensity. That is the basis for social-ecological resistance to fire.

\section{Material and Methods}

\subsection{Methodology}

The field work was carried out in two phases: the first comprised participant observations conducted at meetings of the forest owners' associations in the study area (in 2011); the second comprised interviews with associated forest owners (these interviews were conducted between 2013 and 2015).

Participant observation is a research method that involves social interaction between the researcher and the informants in the field and which allows for the collection of data in a systematic and "non-intrusive" way [97]. Here, we attended a meeting of forest owners and the working commissions of two associations in Central Catalonia: Bages-Vallès (18/02/2011) and Entorns de Montserrat (9/03/2011) which are the two associations that were having meetings during our field work in our study area. We were interested in observing how decisions are taken and what criteria are established for the joint management of the associations' lands. At the same time, we evaluated the extent to which they had been affected by large wildfires and how the forest owners have been able to adapt to the post-fire situation, to determine if they had introduced changes in their management practices. In addition, we attended an Ordinary General Assembly of the Catalan Federation of Forest Owners' Associations BOSCAT, and a round table discussion entitled "Forest Associations in Catalonia. What role should we play?" at Balsareny Castle (Bages) (26-03-2011). Finally, fieldwork was carried out during visits to the Serras de Castelltallat, Pinós and Rubió to see forest management work being undertaken by the Forest Owners' Association of Boscos Bages-Anoia (February 2011).

In the second phase, 28 interviews were conducted with forest owners belonging to the forest owners' associations of Berguedà Verd and Boscos Bages-Anoia. Interviews were conducted one-to-one and were more than one hour long. Each interview was organized around three thematic areas (Table 1).

Table 1. Structure of the interviews around thematic areas.

\begin{tabular}{cl}
\hline Thematic Area & \multicolumn{1}{c}{ Structure } \\
\hline Bloc I: Estate characteristics & $\begin{array}{l}\text { Identification of the estate and of the general characteristics of the } \\
\text { property and its owner, including information about the evolution of the } \\
\text { estate in terms of its characteristics and the activities undertaken on it. } \\
\text { Management of the estate, management characteristics, changes in } \\
\text { management style, including elements related to fire risk management } \\
\text { and the use or otherwise of fire. } \\
\text { Bloc III: Associationism }\end{array}$ \\
$\begin{array}{l}\text { Forest associations, identification of positive and negative aspects } \\
\text { arising from joint forest management, including an evaluation of the } \\
\text { actions undertaken on the estates and in the territory of the association. }\end{array}$
\end{tabular}


Interviews were focused—in the sense established by Merton and Kendall [98]—on the wildfires and the social response that these have generated, treating the interviewees as subjects whose responses to the phenomena studied are of greater interest than their actual role as informants of the event itself [99]—and semi-structured—adhering to the need to maintain a pre-established thematic script that facilitates the homogenisation and comparison of responses [100]. The aim of the interviews was the systematic collection of data concerning the estates and their management. At the same time, it was our objective to examine aspects of the operation of the forest owners' associations, including an evaluation of the tasks they carried out. The interviews combined the stimulus-response format (prefixed questions usually presented in the same order and aimed at capturing more rational responses) with open-ended questions (aimed at capturing what might be deemed more intuitive or emotional perspectives).

The contact of the forest owners was obtained from the listings of associated forest owners provided by the Diputació de Barcelona (Barcelona's provincial council) after first receiving the necessary authorization. The listings included the names of 108 owners, 90 of whom were male and 18 female. We contacted them all and managed eventually to recruit six women and twenty-two men: two under the age of 40 , fourteen aged between 40 and 60, and twelve aged over 60 . As regards ownership rights, 22 were the title holders of the property, there was one case of joint ownership, four cases in which the title holder was someone else (a relative) and one estate that was owned by a company. Twenty of the interviewees were from Berguedà and eight from Bages and Solsonès (Table 2).

Table 2. Information about the associated forest owners provided by the Diputacio de Barcelona.

\begin{tabular}{|c|c|c|c|c|c|c|}
\hline Number & Gender & Age & $\begin{array}{l}\text { Local Administrative } \\
\text { Division-Comarca }\end{array}$ & $\begin{array}{l}\text { Relationship with } \\
\text { the Estate }\end{array}$ & $\begin{array}{c}\text { Estate Size } \\
\text { (ha) }\end{array}$ & $\begin{array}{l}\text { Forest Area in } \\
\text { the Estate (ha) }\end{array}$ \\
\hline 1 & Men & 71 & BERGUEDÀ & Owner & 299 & 271 \\
\hline 3 & Women & 71 & BERGUEDÀ & Owner & 101 & 76 \\
\hline 4 & Women & 76 & BAGES & Owner & 152 & 123 \\
\hline 5 & Women & 51 & BAGES/SOLSONES & Share with others & 9 & - \\
\hline 7 & Men & 88 & BAGES & Owner & 76 & 50 \\
\hline 8 & Women & 49 & BAGES & Owner & 125 & 100 \\
\hline 9 & Men & 57 & BAGES & Owner & 260 & 240 \\
\hline 10 & Men & 69 & BERGUEDÀ & Owner & 45 & 37 \\
\hline 11 & Men & - & SOLSONES & Owner's son & 600 & 500 \\
\hline 16 & Men & 56 & BERGUEDÀ & Owner & 86 & 46 \\
\hline 17 & Men & 40 & BERGUEDÀ & Owner & 150 & 130 \\
\hline 18 & Men & 59 & BERGUEDÀ & Owner & 85 & 82 \\
\hline 19 & Men & 75 & BERGUEDÀ & Owner & 28 & 26 \\
\hline 20 & Men & 48 & BERGUEDÀ & Owner & 80 & 72 \\
\hline 21 & Men & 67 & BERGUEDÀ & Owner & 190 & 130 \\
\hline 22 & Men & 40 & BERGUEDÀ & Share with other/s & 1192 & 968 \\
\hline 23 & Women & 72 & BERGUEDÀ & Owner & 561 & 472 \\
\hline 24 & Men & 53 & BERGUEDÀ & Worker & 1240 & 968 \\
\hline 25 & Men & 60 & BERGUEDÀ & Owner & 204 & 71 \\
\hline
\end{tabular}

The interviews were transcribed and a content analysis conducted. The analysis focused first on the pre-established categories: fire/wildfire, management of the estate before and after the wildfire, and associationism. Then, for each of these categories, responses were grouped according to whether they presented emotional or rational arguments. Our ultimate goal was to identify and understand 
the changes that the owners made in relation to their estate and forestry management practices after the wildfires.

In this way, we were able to analyze the theoretical concepts of social learning and the socio-ecological structures resistant to the fire from the point of view of the forest owners' experiences. Social learning was analyzed from the discourse (definition of objectives and socio-environmental strategies) and the practices (actions) of the associated owners. The construction of resistant socio-ecological structures was also examined by analyzing the owners' discourse and practices, that is, their capacity to generate common spaces, collective discourse, and a socialization of knowledge, with political intent. In addition to these qualitative analyses, we also provide some descriptive statistics showing basically the percentage of answers in each category using Excel and SPSS 20.0.

\subsection{Study Area}

Broadly speaking, Catalonia is a country of forests [101], with $64 \%$ of its territory corresponding to wooded lands, and where $73 \%$ of these lands are private property (Centre de la Propietat Forestal de Catalunya). The rest of the territory comprises croplands (30\%) and urban areas and roads $(5 \%)$. The progressive abandonment of the countryside and the reduction in pasture have led to the advance of the woodland areas and, hence, to an uninterrupted landscape at risk of fire during much of the year, with the forest-urban interface being especially vulnerable. According to the Land Cover Map of Catalonia (CREAF), most of Central Catalonia corresponds to 'Forest Region IV'. This includes the comarcas (i.e., local administrative divisions) of Anoia, Bages, Berguedà, Solsonès and Moianèsa fifth comarca, created in 2015-with a total of 434,209 hectares. This is primarily a mountainous region, where about $60 \%$ of the surface area stands at between 400 and $800 \mathrm{~m}$ a.s.l. with a marked altitudinal gradient that increases from South to North. Across the region, forests are predominant on north-facing slopes (comarcas of Berguedà and Solsonès) and at medium altitudes (with slopes below $30 \%$ ), while shrubland (matorral) and cropland, which increased in area after the large wildfires of 1986, are more frequent in the plains and on south-facing slopes (comarcas of Anoia, Bages Moianès) (Figures 1 and 2).
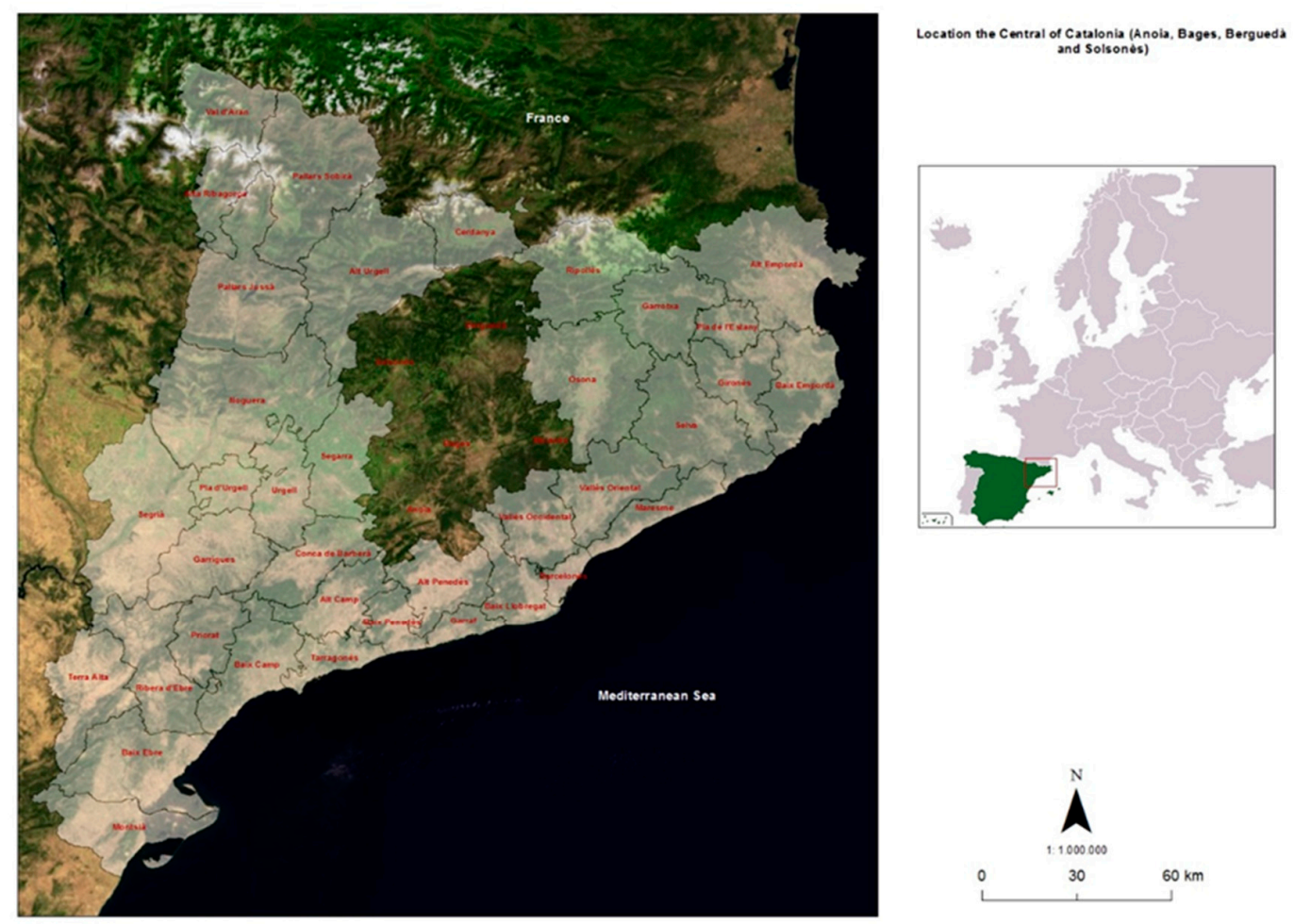

Figure 1. Location of the central areas of Catalonia. 


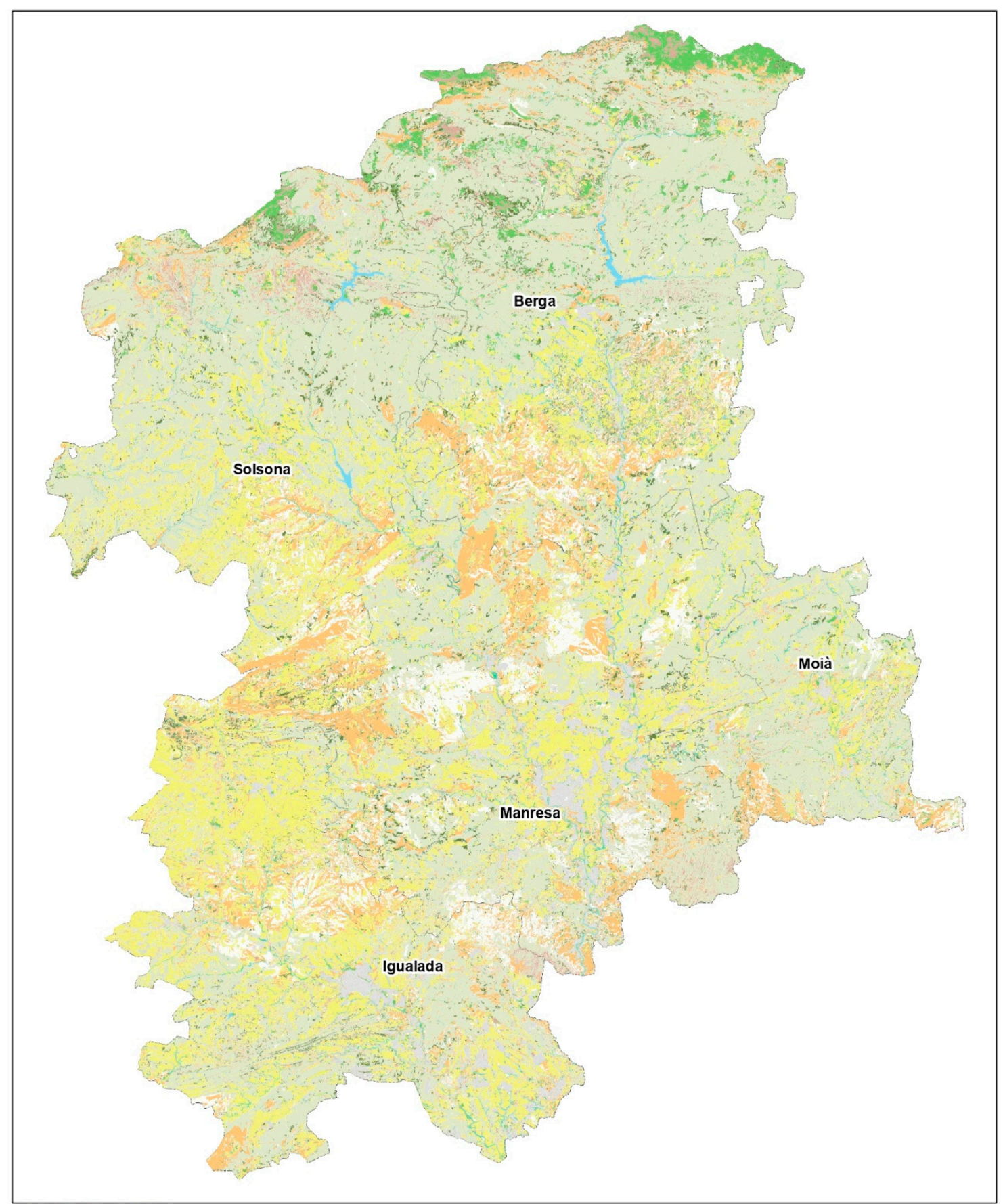

\section{Land Use 2009}

Anoia, Bages, Berguedà, Moianès and Solsonès

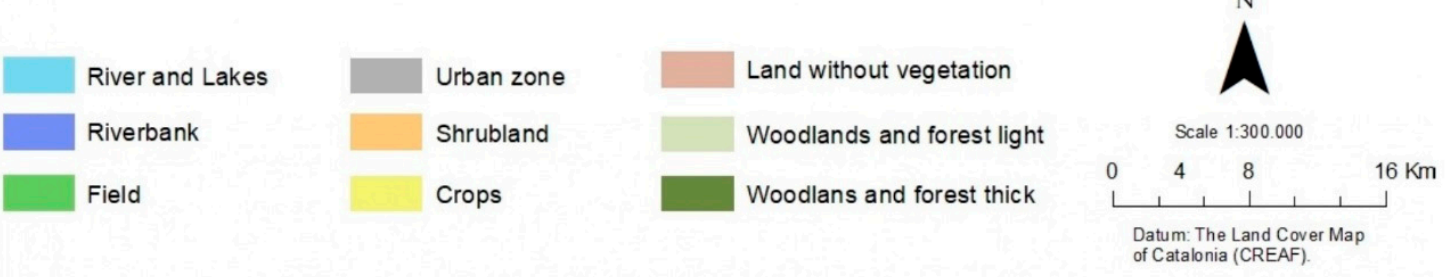

Figure 2. Land use in the study area. 
The region also presents a population gradient running from South to North. The capitals of all the comarcas account for $30-40 \%$ of the population, except in the case of Solsonès, where the percentage exceeds $67 \%$. Bages and Anoia present an urban continuum that generally follows the passage of the rivers and the communication axes, as well as settlements spread throughout most of their territory. Berguedà and Solsonès have a more dispersed population pattern and a more rural population.

The climate results in a predominance of Mediterranean forests in the South of the region, sub-Mediterranean in the central section and Boreo-Alpine forests (above $1600 \mathrm{~m}$ a.s.l.) in the region's northern limits. In the North of the region, the Scots pine (Pinus sylvestris) is the dominant species followed by the black pine (Pinus nigra), and the holm oak (Quercus ilex), with patches of mountain pine (Pinus uncinata) and fir (Abies). In the southern half of the region, pine forests with the Aleppo pine (Pinus halepensis) and holm oak are predominant. The evergreens, together with deciduous trees, especially varieties of oak (Quercus humilis, Q. cerrioids, Q. faginea), and the strawberry tree (Arbutus unedo) located in the margins of the study area, have gained ground in the forest landscapes following the large wildfires of 1986, 1994 and 1998. There are other species of some importance, including the common beech (Fagus sylvatica), located in the comarcas of Berguedà and Solsonès, and the umbrella pine (Pinus pinea), which is relatively abundant in Anoia and Bages (Figure 3).

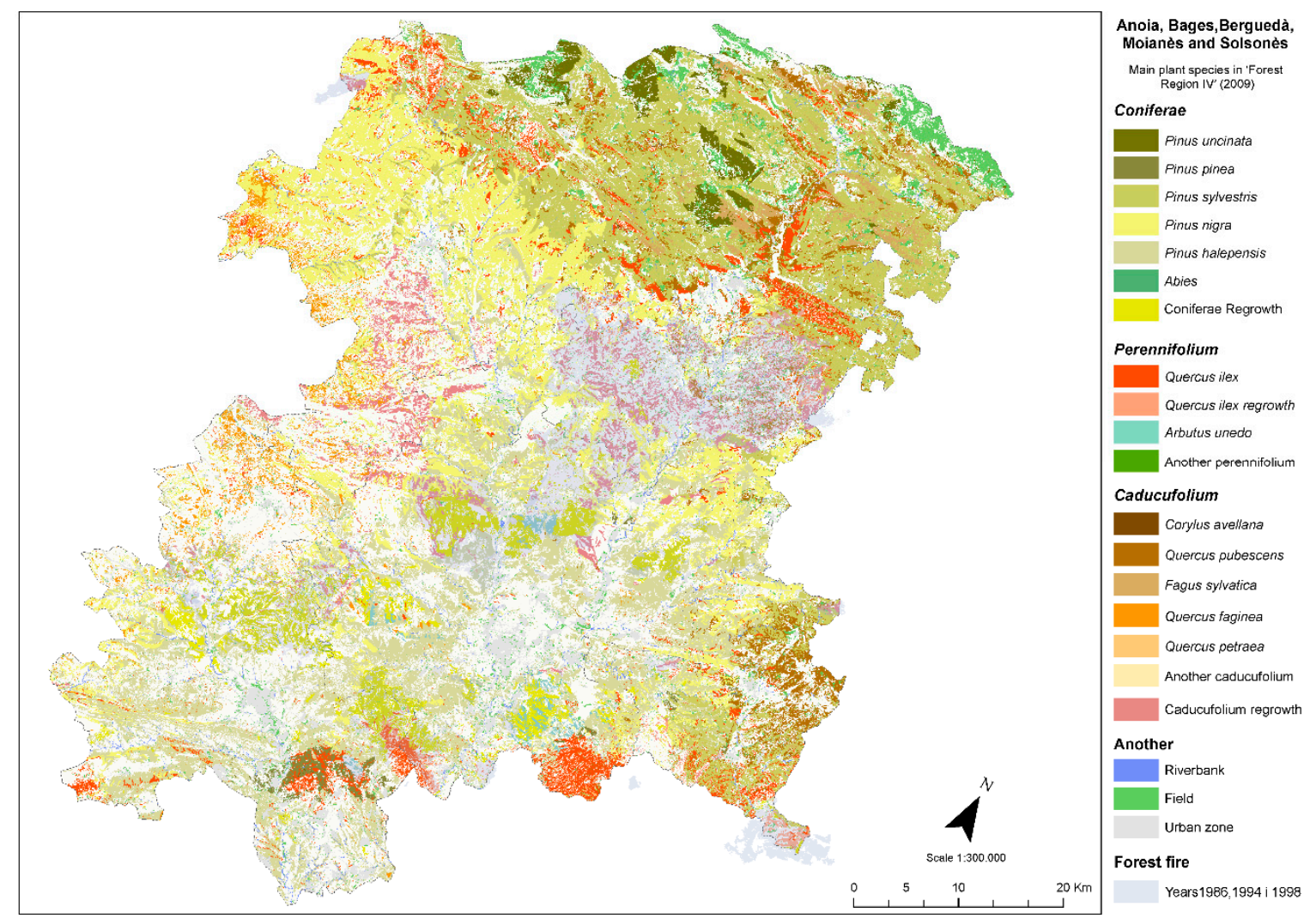

Figure 3. Forest plant species and wildfire perimeters in the study area. (Anoia, Bages, Berguedà, Moianès and Solsonès).

In Catalonia, there are 221,779 forest properties, according to the Forest Property Centre of Catalonia [102]. The distribution of these properties by size is very uneven: while $1.2 \%$ occupy more than 100 hectares and account for more than $40 \%$ of the forest area, $52 \%$ of the properties are very small and occupy less than one hectare, representing less than $3 \%$ of the forest area. Between these, $46.8 \%$ of the properties occupy between 1 and 100 hectares and account for just over $55 \%$ of the forest area (CTFC based on cadastral data). Bages and Berguedà are the comarcas that have the most private forest area in Catalonia with more than 80 thousand hectares, while in Solsonès there are some 70 thousand 
hectares. The forest estates present an average size ranging from 110 to 170 hectares in Berguedà and Solsonès-large by comparison to the Catalan average-and from 90 to 110 hectares in Bages. In Anoia private forested land does not reach 50 thousand hectares (there is less forest area and a greater extent of crop-lands) and its forest estates are the smallest, with properties occupying an average of between 60 and 90 hectares (Figure 4).
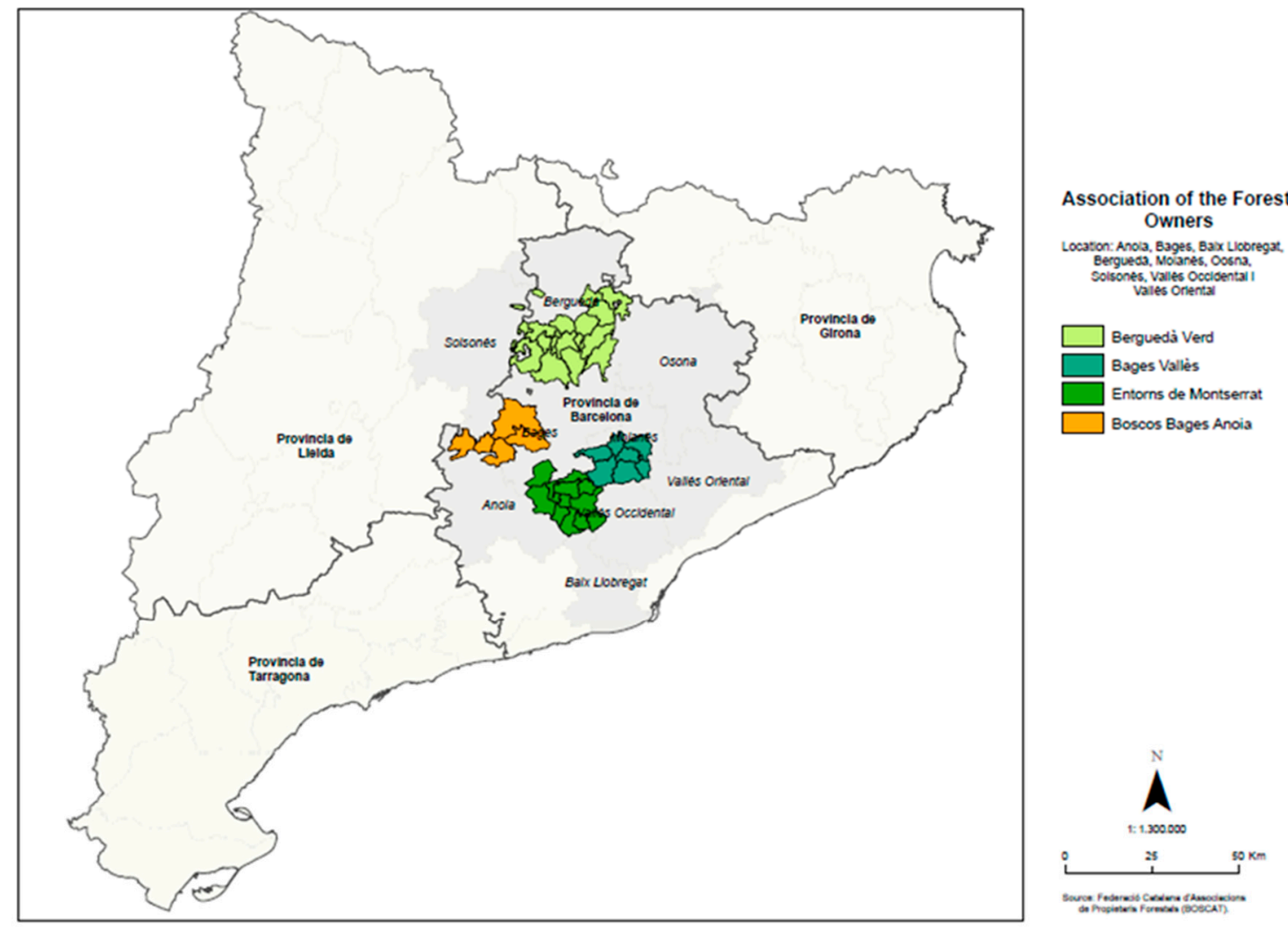

Figure 4. Location of forest owners' associations.

\section{Social Responses to the Large Wildfires in Catalonia}

The first large wildfires in Catalonia, officially defined as those that exceed a burned area of more than 500 hectares, occurred in the 1980s and 1990s, and affected primarily the central zones of the region, and have come to be known as the great fires of Central Catalonia. At the social level, the first forest owners' associations were established in two municipalities in Central Catalonia, in the 1960s with the aim of being able to provide a rapid response in case of fire (before the arrival of the firefighters) and for the members of the associations to meet the costs that, at that time, had to be paid for calling out the firefighters. This was the embryo of the current Agrupacions de Defensa Forestal (ADFs or Forest Defence Groups), under the FOC VERD program, developed by the autonomous government for the prevention of forest fires and reforestation. The ADFs are currently made up of forest and farm owners, entities related to the protection of forests, volunteers and town councils grouped together in their municipal districts, with the aim of preventing, monitoring and fighting forest fires as well as reforesting burnt areas. Today, there are 299 ADFs in Catalonia operating in $69 \%$ of Catalan municipalities.

The forest owners' associations were founded under the protection of a supra-municipal body, the Diputació de Barcelona, and counted on the active involvement of private forest owners, municipal owners and councils. Today, the associations are coordinated through the Catalan Federation of Forest Owners' Associations (BOSCAT). The idea emerged after the large wildfires of 1998, and was supported by Decree 171/2003 of July 8, which declared that the areas affected by forest fires in the comarcas 
of Bages, Berguedà, Solsonès and Osona, and which had not regenerated naturally, required urgent action. The initiative was taken to promote an associated forestry project to foster forest regeneration and, at the same time, to create by means of different management practices in a landscape scale, forest structures that were more resilient and resistant to the passage of fire. The initiative, which was launched in the province of Barcelona, has gradually spread to other provinces, and not only to those affected by fire but to areas affected by other types of disturbance and even to zones of undisturbed green forest.

Despite some progress, the area subject to planning (Table 3) accounts for just $15 \%$ of the entire forested area of Catalonia and this percentage falls to $1.4 \%$ when we speak more specifically of the region's managed forest area.

Table 3. Evolution of the forest owners' associations in Catalonia (1999-2017).

\begin{tabular}{cccccc}
\hline Period & $\mathbf{N}^{\circ}$ Associations & $\begin{array}{c}\mathbf{N}^{\circ} \text { Associated } \\
\text { Owners }\end{array}$ & $\begin{array}{c}\mathbf{N}^{\circ} \text { Municipalities } \\
\text { Involved }\end{array}$ & $\begin{array}{c}\text { Total Planned } \\
\text { Area (ha) }\end{array}$ & Actions (ha) \\
\hline $1999-2009$ & 14 & 610 & 103 & 137,829 & 18,000 \\
$2010-2017$ & 22 & 1167 & 147 & 301,000 & 29,000 \\
\hline
\end{tabular}

Own elaboration based on Diputació de Barcelona data.

\section{Results and Discussion: Post-Wildfire Responses at Individual and Community Levels}

\subsection{Forest Owner's Responses (Emotional, Rational and the Results Actions) after Forest Fires}

\subsubsection{Emotion}

Generally speaking, fire-even though almost two decades have passed since this area was affected by the large wildfires-is still uppermost in the minds of the forest owners. Most of those interviewed (93\%) expressed just how devastating the fires had been in terms of the damage (physical and emotional) inflicted. A third of respondents manifest feelings of collective dismay, frustration, even impotence at not having been able to prevent their spread. The words of three owners are highly illustrative of these feelings:

"The fires of 94-98 and 2000 are still very much in our minds. Their memory cannot easily be erased and the people around here are still deeply affected."

"After the fires you're left dumbstruck, quite unable to react. For years you've managed your trees, ensured that the landscape is as it should be, but the efforts of all those years go up in flames in a matter of hours, the sense of dismay is overwhelming."

"My source of income has vanished, the fires have impacted me financially and morally, devastating the landscape."

In this respect, our research results are very similar to those reported by Domínguez [103] who stresses the sense of fatalism expressed by the owners in the face of the fire and of forming part of a highly vulnerable community [104]. As one owner remarked, "at any given moment, everything can go up in flames".

\subsubsection{Reason}

Three specific types of thinking emerge from the interviews. First, there is the idea of the inevitability of fire, and the fact that the wildfires might strike again at any time. Over $50 \%$ of the forest owners interviewed believe that wildfires could be a problem in the future (see Table 4) and one forest owner considered it to be quite impossible to prevent his estate from burning again:

"In 1964 we planted 5000 black pine trees and from 1964 to 1994 we were a model plantation; yet, everything was lost in the fire!" 
Yet, one owner actually questioned whether it was really such a disaster when a forest fire broke out:

"We were well warned. We are well aware of forest fires. Sometimes I wonder if it really is such a disaster when the forest burns. Maybe it's not such a problem, fire is just part of the forest, it regenerates the trees, it might be an opportunity..."

Another owner explained: "it affects us but we must learn to live with it."

Table 4. Expected medium- and long-term problems in the state.

\begin{tabular}{ccc}
\hline Natural Disturbances & $\begin{array}{c}\text { Medium Term Problems } \\
\text { (Number of Responses) }\end{array}$ & $\begin{array}{c}\text { Long Term Problems } \\
\text { (Number of Responses) }\end{array}$ \\
\hline Forest fires & 14 & 8 \\
Climate change & 1 & 2 \\
Pest & 5 & 2 \\
Rural abandonment, lack of forest management & 5 & 4 \\
Loss of forest area & 3 & 1 \\
Other (over-frequency, too much regulation...) & 2 & 3 \\
\hline
\end{tabular}

Several owners gave more than one answer.

Second, the forest owners note a change in the fire typologies. They report that they are much more destructive today (in fact, six of the owners referred to them as "the great wildfires") and thought little could be done to fight them (nine responses):

"You can't do anything, either there's a heat change or the fuel runs out, That is all there is to it. You learn that from the Defence Group and you have to learn it for yourself."

Or as another owner explained:

"You learn that in adverse weather conditions, it is impossible to stop the fire - 40 degrees, $10 \%$ humidity and winds between 40 and $50 \mathrm{~km} / \mathrm{h}$, all occurring together."

Our inability to bring major forest fires under control is a matter that has long been reported by experts in the field of fighting wildfires [105].

While aware of the difficulties, the interviewees were asked what solutions they might suggest for fighting forest fires. One respondent claimed:

"With the Defence Group, before a fire, paths are built and clearings made to ensure fuel loads are low. But, anyway, what is prevention? Firefighters? In '94 nothing was effective against the scale of that fire - the paths, the firebreaks, the fire simply jumped over everything..."

It also helps to consider management strategies, in order to try to increase their efficiency and to avoid the spread of a great fire:

"Yes, the fire makes you aware of many things. A clearing that me, my father and grandfather thought would provide a firebreak, was quickly overwhelmed and the fire burned everything."

Davis [106] and Agee et al. [107] claim that linear fire prevention infrastructure (firewalls and perimeter strips) have limited effectiveness. Costa et al. [108] and Piqué et al. [109] argue that the strategies for preventing and extinguishing wildfires need to be jointly planned. This means reducing the possibilities of a large wildfire spreading and minimizing the threat to persons, properties and landscape uses by employing measures of strategic prevention at the appropriate territorial scale. 
Third, and finally, a distinction emerges between the causes of the fires and the structural factors that favor large wildfires. Those interviewed explained that fire outbreaks are closely associated with the characteristics of the Mediterranean climate ( $89 \%$ of respondents). They offer an unequivocal diagnosis of the factors favoring large wildfires, in addition to the climate (Table 5), distinguishing between structural and circumstantial factors. For example, they report in relation to the planting of pine trees that while such forests are more profitable financially the trees burn more easily than oak and holm oak: "Pine burns a lot but we like pine forests a lot".

Table 5. Factors favoring large wildfire.

\begin{tabular}{ccc}
\hline Type of Factor & Factors Favoring Wildfire & Number of Responses \\
\hline \multirow{2}{*}{ Circumstantial factors } & Adverse weather conditions (high temperatures, wind, & 11 \\
& low humidity, drought) & 4 \\
\hline & Human factor (farm machinery, recklessness, power lines) & 6 \\
Structural factors & Dense forests due to lack of management & 3 \\
& Increase of the forest area & 3 \\
& Predominance of pine forests & 2 \\
& Loss of cultivated fields & 1 \\
\hline
\end{tabular}

Several owners gave more than one answer.

\subsubsection{Action}

Domínguez [103] reports that forest owners hold two conflicting views in relation to the risk of wildfires: some believe that the risk can be reduced by human intervention while others hold that management is irrelevant in the face of fire. In our study, the forest owners interviewed belong primarily to the first group; that is, they are optimistic about the benefits of human intervention ( $68 \%$ of responses). Fifty per cent of the owners interviewed believe that management practices should be changed, not specifically in order to eliminate fire, but rather with the aim of creating forest structures that are resistant to its passage and which can reduce the risks presented by large wildfires:

"We should try to manage the forest differently to avoid a great wildfire."

The other fifty per cent of forest owners make specific reference to other fire prevention tools, such as the maintenance of roads and infrastructure, and the need to provide the ADFs with more material support. Among the first group, $79 \%$ of owners believe that forest management conducted through the associations can constitute an effective tool of fire prevention. The remaining $21 \%$ were more specific in stating that this idea should be developed through "actions that can provide a wider territorial perspective, beyond the individual state" or by "creating joint security areas, depending on the specific behaviour of the wildfire".

It is worth noting that the ideas forwarded by the forest owners are in line with the more innovative proposals that have been made within the field of prevention management, which advocate the prevention of wildfires at the landscape scale. Preventive interventions are prioritized in specific areas deemed strategic in terms of wildfire behavior. The objective, as such, is to attempt to modify the behavior of wildfires so that they can be more easily extinguished and to ensure they do not become large wildfires [16]. Additionally, to understand fire regimes in all their complexity, to the critical factors of fuel, climate and ignition, we should add a fourth, namely, fuel structure $[4,110]$. Thus, preventive interventions need to promote forest structures that are resistant to the spread of wildfires and which reduce their intensity $[4,16,111-114]$. Similarly, they might also usefully promote the resilience of forest ecosystems to the effects of wildfires [16,93]. 
The management proposals made by the respondents fall mainly into four lines of action:

(1) Incorporating livestock (mainly cattle) to graze in forest areas, in order to reduce forest fuel, as part of a program promoted among the forest owners' associations by the Diputació de Barcelona (71\% of the forest owners interviewed).

(2) Fostering the production of biomass as a medium-term measure for the economic exploitation of forest fuel. Indeed, 15 owners use firewood on their estates (in some cases, various homes are located on the forestry estates) in traditional wood-burning fireplaces (nine responses), but also in other heaters and biomass boilers. The respondents claim that it is cheaper than using pellets (eight responses) or wood chips (three responses) and that it has the advantage that it can be collected from their estates and so they avoid any transformations costs. Yet, our interviewees indicated that gas heaters are widely employed; indeed, 13 owners use them, while four use combined gas and firewood heaters.

(3) Favoring a forest management that guarantees mixed forests of conifers and broadleaf trees (75\% responses) as opposed to single species forests, as well as promoting the recovery of areas of cultivation (on $46 \%$ of the estates), even though they may be small (between 5 and 10 ha).

(4) Implementing prescribed burning as a means to reduce biomass, although this generates greater reservations among respondents (Table 6), in line with the conclusions reported by Fischer and Charnley [26]. Yet, despite the lack of agreement on the use of controlled burns among the association members, it does not seem to represent an obstacle to cooperation. The reasons for the reticence to employ prescribed burning include ignorance regarding its potential results, doubts as to whether it can be beneficial for the forest (similar to the conclusions reported by Piatek and McGill [115]), and a preference for other options, such as the use of more efficient and selective tools. In contrast, those owners that have participated in controlled burns, or who have knowledge of them, do not rule out their use and see them as an ancient practice employed by farmers. In this regard, associations can become a space for socializing knowledge of the use of fire as a management tool [116].

Table 6. Advantages and disadvantages of prescribed burning.

\begin{tabular}{clcc}
\hline Against Prescribed Burns & \multicolumn{2}{c}{ Favorable to Prescribed Burns } \\
\hline Scary & 4 & Good for cleaning & 3 \\
Non-selective practice & 3 & Good for Fire prevention & 3 \\
Lack of knowledge & 3 & Ancestral practice & 2 \\
Doubts about the benefits & 3 & Selective practice & 1 \\
Not necessary & 1 & We have already done & 3 \\
I don't want to see fire & 1 & If it works, why not & 2 \\
it doesn't work, it fails & 1 & & \\
\hline
\end{tabular}

None of the management practices being adopted are new (extensive livestock, biomass, use of fire), indeed, all are traditional practices; however, by exploiting technological improvements and current specialized knowledge, they are once again being implemented. The results are shown in this table (Table 7). 
Table 7. Forest owners' responses (emotion, reason and action) to forest fires.

\begin{tabular}{ll}
\hline & Forest Owners' Responses \\
\hline \multirow{3}{*}{ Emotion } & Collective dismay \\
& Frustration \\
& Impotence \\
& Deep pain \\
\hline \multirow{3}{*}{ Forest Fires } & Inevitability of fire \\
& Change in fire behavior \\
& Distinction between the causes of the fires and the Structural \\
& factors that favor the great fires \\
\hline & Incorporating livestock in the forest \\
& Economic exploitation of biomass \\
& Mixed forest, avoiding monospecific forest \\
& Prescribed burning (not agreed by everyone interviewed) \\
& Forest management as a tool of fire prevention \\
& Actions with a wider territorial perspective \\
\hline
\end{tabular}

5.2. Forest Owner's Responses (Emotional, Rational and the Results Actions) in Post-Fire Estate Management

\subsubsection{Emotion}

One aspect highlighted by the interviewees ( $46 \%$ of respondents) is the feeling of loss-economic, patrimonial and cultural-felt after the fires. The landscape has changed beyond recognition, part of the forest has disappeared and as it regenerates new species replace the old. Life on the forest estate has also changed: the future is uncertain and some respondents speak of a sense of disorientation when it comes to deciding how they should continue. As one forest owner put it:

"25 years ago, everything got burned and was lost, so we couldn't live off the forests any more.

Zero forest profit!"

More than half the owners (57\%) explained that they have learned all they know about forest management from their families, knowledge that has been passed down from generation to generation, from grandparents to children and the children's children. Some of the interviewees (10\%) expressed their fear of "losing this tradition", in reference to the exploitation and management of the forests after the wildfires. Domínguez [103] confirms this, arguing that good forestry practices are learnt during childhood. Traditionally, in Catalonia, the owners managed the forest estate in a piecemeal fashion, implementing only occasional actions, depending, that is, on the individual owner and on the characteristics of the estate $[117,118]$. This approach is apparent in some of our interviews, for example:

"We never used to clearcut the forest, we always cut selectively. You'll find 5-6 tree sizes of different ages in our woods. Every 10 to 12 years you felled an area again and over a period of 40 to 50 years you'd cut everything down, but there'd always be trees, you'd only cut the old, big ones."

Others conduct more periodic fellings:

"Before, each year you did some cutting in one specific place, so over a period of 10 to 12 years you worked your way around the estate."

"In these forests, wood was cut every 6 years but now we can't do that."

"My father was a lumberjack. Every seven years he used to fell the trees for those owners who trusted him to do the job well. That kept the woods young. My father knew a lot, he loved the woods very much." 


\subsubsection{Reason}

One of the issues that explicitly emerges from the owners' discourse is the significant change recorded in the forests' tree species after the fire; thus, those species traditionally considered more productive and more economically profitable and which for decades had been grown for their subsequent exploitation, have disappeared from broad swathes of territory. In this case, the conifers (Scots pine Pinus sylvestris and the black pine Pinus nigra subsp. salzmannii) have been replaced by what is supposedly the territory's potential natural vegetation, above all oak (Quercus $s p$ ), sometimes mixed with holm oak (Quercus rotundifolia) or strawberry tree (Arbutus unedo). Where conifers do regenerate, it is the Aleppo pine (Pinus halepensis) that is dominant with woods of a very dense forest structure. The fires have also increased the areas of different land covers, including garrigues (low, soft-leaved scrubland), màquies (densely growing evergreen shrubs), and dry pasture (with a predominance of Brachypodium phoenicoides).

In relation to these landscape changes, some of the owners draw comparisons with earlier periods, and they highlight two key moments in this evolution: one, between the beginning and the middle of the 20th century, characterized by the exploitation of the forest area, along with its cultivation, above all in the form of vineyards and other croplands, which were subsequently abandoned and reforested; and the other, the dramatic change ushered in as a result of the large wildfires of the 1990s. This extract taken from an interview with a forest owner in Berguedà is illustrative of this:

"Fifty years ago, you could live off the woods. There were many small terraces with vines and little cereal. Twenty-five years ago, it all burned and we went from living off the woods to nothing-zero exploitation of the forests! As for the tree species, this has always been an estate of oak and holm oak, as my grandfather used to say. During the war, the trees were cut down and the Aleppo pine and black pine became dominant. The main change after the fires is that we have gone from the Aleppo pine and black pine back again to oak and holm oak, but above all oak trees."

It would appear that one of the first aspects in relation to which learning appears to have taken place concerns the emergence of the idea of the landscape as a dynamic, changing force (subject not just to minor changes), as opposed to the landscape seen as a static entity characterised by a highly conservationist perspective of ecosystems. Bolòs et al. [119] claim that while change tends to be naturally slow, there are exceptions to this that are perhaps more frequent than we might imagine; for example, the sudden transformations associated with wildfires, landslides, plagues and floods, and to understand them, both natural and social factors have to be taken into account. For example, human activity can modify fire regimes. According to Guixé et al. [118]: “The landscape is alive, it shifts and changes according to the social and environmental characteristics of the territory".

It is our firm belief that appreciating the fact that landscapes are dynamic and that forest fires n.y(among other factors) are elements of change in Mediterranean landscapes is essential since only in this way can we hope to establish the bases of a new socio-ecological relationship, a new way of coexisting with forests, especially under the threat of large wildfires.

\subsubsection{Action}

Following the great changes wrought by the fires, the need arose to manage this new reality: on the one hand, on most estates ( $46 \%)$, the owners explain that after the fire it was decided to increase the area dedicated to crops, usually by less than 10 ha. Moreover, the owners who had previously obtained most of their income from forestry were now forced to find new sources, and so we find farm estates that took up intensive (39\%) and extensive livestock farming (71\%). Alongside this, we see the emergence of rural tourism ( $36 \%$ of the estates). As for the forests on the estate, the owners have been forced to rethink their management in terms of their economic, social and environmental viability. There are owners who, from the outset, have sought to recover the species that grew before the fires (a traditional response according to Weber [62]). Hence, eight of the interviewees (29\%) reported having replanted pine trees, but three of them recognize that they are unlikely to thrive. 
However, there is some debate concerning the need to rethink forest management, in the face of changes in the predominant plant communities and their structure, and how best to integrate long-standing practices and knowledge. In the Bages-Vallès association, the debate centers on where to act first-on the oak or holm oak forest? In their deliberations, it is argued that the holm oak is in greater need of management, as up to 30 offshoots can be found per tree while the oak "looks after itself", with just 2 or 3 offshoots per tree. A further consideration is the fact that in the oak forest the presence of the strawberry tree (Arbutus unedo) is notable, a presence that would increase management costs and mean, owing to budgetary constraints, that actions would be limited to a smaller area.

Where the debate about the strawberry tree is most intense is in the Montserrat association. Two distinct points of view are expressed: one that favors the management of the strawberry tree so as to promote ecological values, biodiversity and landscape quality, and another that prioritizes the management of oak and holm oak for their future exploitation as a forest resource (economic values). This second group of owners argues that "we do not want a garden" but rather a forest from which, "in the long run we can make a living".

In fact, the most frequent response given by the owners (33\%) when asked why they manage their estate was "for economic motives": $13 \%$ with the idea of obtaining immediate (short-term) benefits and the remaining $20 \%$ with a more long-term vision, for the next generation (zweckrational actions, Weber [62]). But this response is closely followed (27\%) by those who claim they manage their forests for "emotional motives" (for sentimental reasons, out of a sense of duty to the property owned, to the family and also to the wider territory and the way of life of the farmer) and also out of the need to conserve nature ( $25 \%$ of the responses), thinking very much about future generations (wertrational actions as suggested Weber [62]). Those who refer to managing their estates to protect them from wildfires (13\% of responses) have both practical and emotional motives (Tables 8 and 9). Indeed, ensuring a well-managed forest (a highly complex and polysemic concept, as noted by Rodríguez-Carreras et al. [27] and Domínguez [103]), so as to avoid a repetition of large wildfires, also emerges as a reason of some weight (Table 10).

Table 8. Reasons for managing the forest estates.

\begin{tabular}{|c|c|c|c|c|c|}
\hline Interviews & $\begin{array}{l}\text { Short-Term } \\
\text { Economic }\end{array}$ & $\begin{array}{l}\text { Long-Term } \\
\text { Economic }\end{array}$ & $\begin{array}{c}\text { Emotional } \\
\text { Motives }\end{array}$ & $\begin{array}{c}\text { To Conserve } \\
\text { Nature }\end{array}$ & $\begin{array}{l}\text { To Avoid } \\
\text { Wildfires }\end{array}$ \\
\hline 1 & $x$ & & & $x$ & \\
\hline 2 & & $x$ & $x$ & & \\
\hline 3 & & & $x$ & & \\
\hline 4 & & $x$ & $x$ & & \\
\hline 5 & & $x$ & & & \\
\hline 6 & & $x$ & & & \\
\hline 7 & & & $x$ & & \\
\hline 8 & & & $x$ & & \\
\hline 9 & & $x$ & & & \\
\hline 10 & & & & $x$ & \\
\hline 11 & $x$ & $x$ & & $x$ & \\
\hline 12 & & $x$ & & $x$ & \\
\hline 13 & & $x$ & $x$ & & $x$ \\
\hline 14 & & $x$ & $x$ & $x$ & $x$ \\
\hline 15 & $x$ & & & $x$ & \\
\hline \multicolumn{6}{|l|}{16} \\
\hline 17 & & & $x$ & $x$ & $x$ \\
\hline \multicolumn{6}{|l|}{18} \\
\hline 19 & $x$ & & & $x$ & $x$ \\
\hline 20 & & & $\mathrm{x}$ & & \\
\hline
\end{tabular}


Table 8. Cont.

\begin{tabular}{cccccc}
\hline Interviews & $\begin{array}{c}\text { Short-Term } \\
\text { Economic }\end{array}$ & $\begin{array}{c}\text { Long-Term } \\
\text { Economic }\end{array}$ & $\begin{array}{c}\text { Emotional } \\
\text { Motives }\end{array}$ & $\begin{array}{c}\text { To Conserve } \\
\text { Nature }\end{array}$ & $\begin{array}{c}\text { To Avoid } \\
\text { Wildfires }\end{array}$ \\
\hline 21 & $\mathrm{x}$ & $\mathrm{x}$ & $\mathrm{x}$ & $\mathrm{x}$ & \\
22 & & $\mathrm{x}$ & $\mathrm{x}$ & $\mathrm{x}$ & \\
23 & & $\mathrm{x}$ & $\mathrm{x}$ & $\mathrm{x}$ \\
24 & $\mathrm{x}$ & $\mathrm{x}$ & $\mathrm{x}$ & $\mathrm{x}$ \\
25 & $\mathrm{x}$ & $\mathbf{1 0}$ & $\mathbf{1 4}$ & $\mathbf{1 3}$ & $\mathbf{7}$ \\
26 & $\mathbf{7}$ & $36 \%$ & $50 \%$ & $46 \%$ & $25 \%$ \\
27 & $25 \%$ & $20 \%$ & $27 \%$ & $25 \%$ & $13 \%$ \\
\hline $\begin{array}{c}\text { Total } \\
\text { Percentage per }\end{array}$ & $13 \%$ & & & \\
\hline $\begin{array}{c}\text { Ttem }(\%) \\
\text { Total/ }\end{array}$ & & & & & \\
\hline
\end{tabular}

Table 9. Relation between reasons offered for managing the forest estates.

\begin{tabular}{lc}
\hline \multicolumn{1}{c}{ Motives } & Number of Responses \\
\hline Short-term economic + to conserve nature & 6 \\
Short-term economic + to prevent wildfires & 2 \\
Long-term economic + emotional motives & 5 \\
Long-term economic + to conserve nature & 3 \\
Long-term economic + to prevent wildfires & 1 \\
Emotional motives + to conserve nature & 6 \\
To conserve nature + to prevent wildfires & 5 \\
Emotional motives + to prevent wildfires & 5 \\
\hline
\end{tabular}

Table 10. Forest owners' responses (emotion, reason and action) in post-fire estate management.

\begin{tabular}{cll}
\hline & Emotion & $\begin{array}{l}\text { Feeling of economic, patrimonial, cultural and ecological loss } \\
\text { emotional reasons for managing the estate. }\end{array}$ \\
\cline { 2 - 3 } \begin{tabular}{c} 
Estate management $\begin{array}{l}\text { Reason } \\
\text { Post-fire }\end{array}$ \\
\cline { 2 - 3 } Action
\end{tabular} & $\begin{array}{l}\text { Change of species and predominance and densification of vegetation } \\
\text { Landscape as a dynamic changing force, as opposed to a static entity } \\
\text { Forest fires as elements of change in Mediterranean landscapes }\end{array}$ \\
\cline { 2 - 3 } On the estate & $\begin{array}{l}\text { Increase the hectares dedicated to crops } \\
\text { Intensive livestock farming } \\
\text { Rural tourism }\end{array}$ \\
\hline In the forest & $\begin{array}{l}\text { Try to recover species that grew before the fires } \\
\text { Promote a mixed forest } \\
\text { Debate about management based on biodiversity and landscape } \\
\text { criteria or economic criteria }\end{array}$ \\
\hline
\end{tabular}

\subsection{Strategies of Cooperation between Owners: Forest Associations}

The reasons presented by the owners in favor of associated management (In Catalonia, the creation of voluntary, non-profit associations (under Law 7/1997 of June 18) provides for the joint management of forest areas of between 30 and 40 thousand ha, with all decisions being taken in a consensual fashion among the entities involved. Each association appoints a forestry technician, who takes an advisory role and is responsible for the drafting of the Framework Plan and scheduling the annual program. The Plan outlines both the association's objectives and actions for a period of between 20 to 25 years, thus committing forest owners and managers to medium- and long-term goals. The associations comprise a working committee that meets periodically to discuss the main actions to be implemented. A General Assembly also convenes annually to discuss all proposals and to evaluate the results, 
thereby allowing owners and managers to exchange views and to lay the foundations of a small-scale associative tradition in forestry) are likewise a mixture of rational-instrumental and emotional motives:

- Strategic/cooperative: the forest is a continuous, unbroken landscape, which means planning can be implemented at a scale larger than that of just one single estate. Joint strategies can therefore be sought to deal with such problems as large wildfires:

\section{"People need to be convinced of the benefits of joint planning in the fight against wildfires."}

These opinions are very similar to those recorded by Amacher et al. [25], Fischer and Charnley [26] and Jarrett et al. [28]. In our study, 32\% of forest owners value positively the cooperative nature of the associations which facilitates the joint planning of management strategies.

- Economic: by exploiting scale economies, costs can be lowered if one company manages a larger area of forest, rather than a number of small estates. At the same time, it allows estates to be more competitive when devising sales campaigns for their forest products. Moreover, after the fires, there are costs that the owners claim they can little afford. Indeed, half the respondents $(50 \%)$ consider that one of the benefits of joint forest management are the economic benefits.

- Bureaucratic: the associations serve as a means of streamlining post-fire management procedures and implementing joint management systems, fostering cooperation strategies in the coordinated management of entities. Of the owners, $17 \%$ recognized this advantage.

- Political: $17 \%$ of respondents consider that being part of an association endows them with greater strength when dealing with government bodies. Associations that have a broad social base enjoy greater social legitimacy for negotiating a territory's forestry and rural policies. Moreover, the fact that all the associations are further coordinated at the regional level by BOSCAT means they have a role to play as political subjects in defining public forestry policies that help project "the landscapes of tomorrow" [24].

- Emotional/sentimental: $14 \%$ of the owners consider that being part of an association enables them to meet the need to share experiences and cooperate and to take joint decisions to tackle broader problems. This sense of union-sharing experiences and building a common narrative and discourse-reinforces what González-Hidalgo et al. [120] identify as a feeling of resistance, a resilience linked to the self-construction of its own subjectivities strongly rooted in the territory and a collective feeling with a shared identity that can help strengthen peoples' ties to that territory.

The forest owners' associations have emerged as a strategy for achieving more fire-resistant socio-ecological structures: social, because they seek to cope jointly and consensually with the management of forest landscape in their attempts to deal with a socio-environmental problem (as represented here by large wildfires), creating networks of solidarity and collective action that generate social structures ready to respond when necessary; and ecological because by implementing measures of forest management, the aim is to reduce the risk of large wildfires and their effects, by creating more fire-resistant landscape structures. This is possible by recovering the agroforestry mosaic and reducing fuel in those strategic areas in a landscape management. At the same time reinforcing alliances between forest owners, also between the owners and the rural world. Maybe this should arrive to the whole society. An important part of the socio-ecological resistance includes enhancing the social, economic, ecological and landscape values of the forest and communities, and understanding these values in an interrelated fashion.

Associationism is a strategy linked to an objective that is developed through concrete actions (Figure 5). Cooperation should, in the long term, further empower the community, as it shares its knowledge and experiences to create a collective discourse on forest management and forest fires, and as it strengthens its constructive influence on forestry policies. By connecting social and forestry/environmental structures a tool should emerge for creating social links and ties of identity in the same territories. Here, the respondents' appreciation of the actions being carried out by the associations demonstrates the legitimacy and power of deliberation and consensus. 


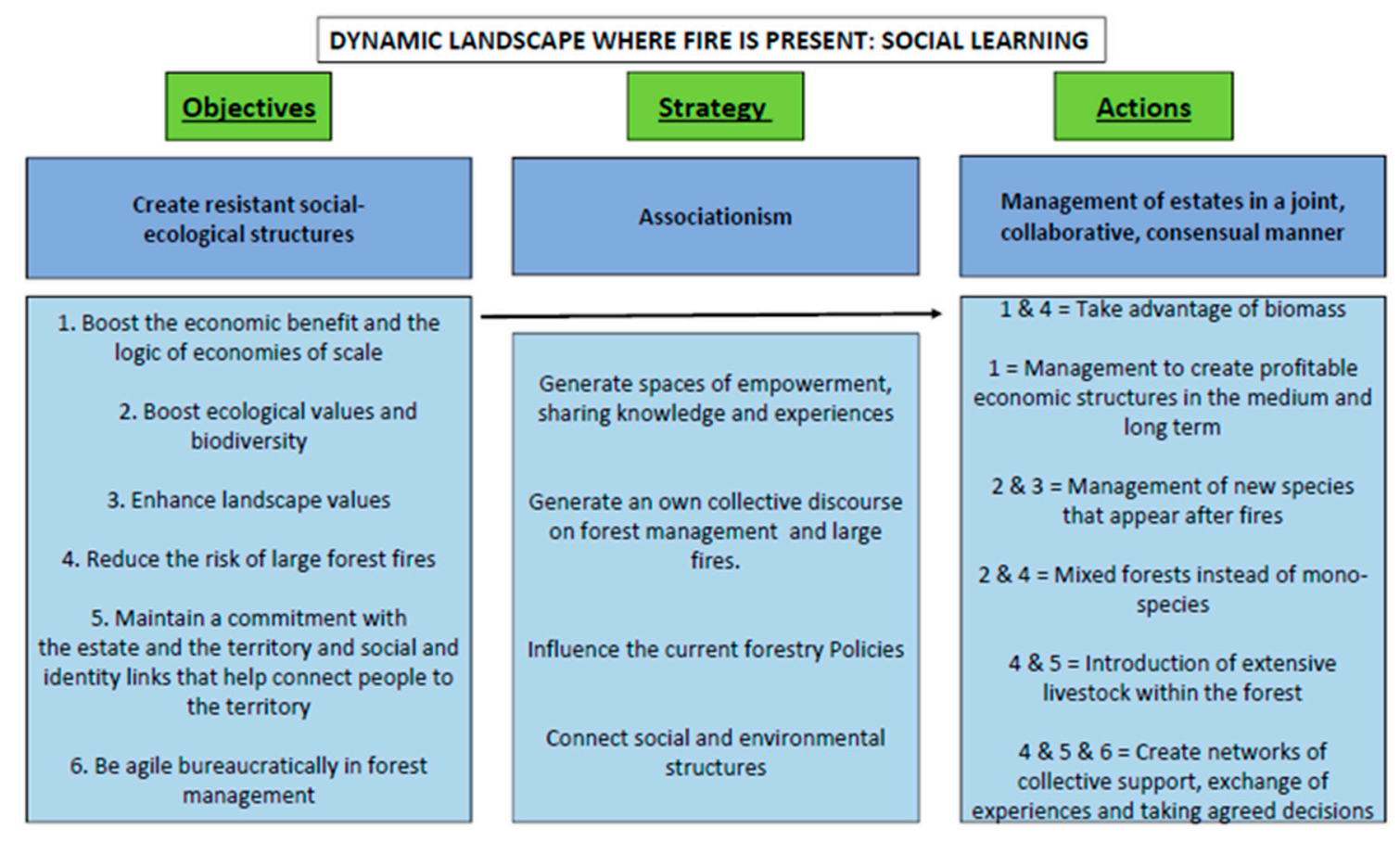

Figure 5. Social learning process identified in this study.

A good example of the way in which the deliberative process pursues the general as opposed to individual interests [48] when it comes to managing the associations' forests is illustrated by the work of the Bages-Vallès association. In its founding Framework Plan, it was agreed that only those properties that had been affected by large wildfires, in particular those of 1986, would be managed. However, there are estates that have a strategic role to play in the case of fire prevention, but as they had gone unaffected by fire were unable to form part of the association from its outset. These estates are now being incorporated with the drafting of the new Framework Plan for the entire forest area (burnt and mature). In the association, deliberations are now underway to consider the decisions in terms of fire prevention efficiency and to constitute an effective global plan for the association's territory. What is proposed, therefore, is a so-called 'oil-stain' strategy, based on technical criteria (namely, vegetation height and density). It involves the selection of two estates in densely replanted zones-one in the east, the other in the west-where forestry management work can be initiated. The idea is that the 'oil-stain' of forestry actions will then spread from the extremes of the association's territory and meet in the center.

\section{Conclusions}

The large wildfires of the past, despite their severity and their immediate repercussions for the landscape, environment and society, can represent an opportunity if appropriate social responses are taken. In the previous sections, we have shown how these responses relate to both emotional and rational elements of the forest owners' reactions, with the actions taken being the outcomes of social learning. Associationism and the management of estates in a collaborative and consensual manner have emerged as strategies linked to objectives identified by the associations and their members. These objectives form the constructs of the socio-environmental structures that aim at being resistant to large wildfires and which act as a link between social structures and territories and between the environment and nature. We have observed how associations impact the natural environment by seeking to create forest structures and so landscape structures that are less likely to be affected by large wildfires

As a result of learning, two ideas stand out: on the one hand, the understanding of forests as a dynamic landscape - this is where the ecology meets society—and on the second hand, related to 
the first idea, the inevitability of fire as part of the forest ecosystem, so we must learn to live with it. Individuals need to have a good understanding of large wildfires and they need to be able to appreciate their structural causes. The possibilities of bringing about a required transformation depend as much on being able to undertake rational and emotional analyses of situations and facts as they do on finding answers in relation to an intended goal. Therefore, conscious social action, with responses oriented to an instrumental and (preferably) an ethical goal, constitute the forces underpinning any structural transformation. What is undeniable is that the ability to integrate these changes and to adapt to these new situations depends on the survival of the overall structure; it is here that learning lies.

Author Contributions: Conceptualization, R.R.-C. and M.F.; methodology, R.R.-C. and X.Ú.; software, C.M.; validation, R.R.-C.; formal analysis, M.F.; investigation, R.R.-C. and X.Ú.; resources, X.Ú.; data curation, R.R.-C.; writing—original draft preparation, R.R.-C. and M.F.; writing—review and editing, R.R.-C. and M.F.; visualization, X.Ú. and C.M.; supervision, X.Ú.; project administration, X.Ú.; funding acquisition, X.Ú. All authors have read and agreed to the published version of the manuscript.

Funding: This study was made possible thanks to Projects CGL2013-47862-C2-1-R and POSTFIRE_CARE Project (CGL2016-75178-C2-2-R [AEI/FEDER, UE]) sponsored by the Spanish Ministry of Economy and Competitiveness and the European Union via European Funding for Regional Development (FEDER). We also enjoyed the benefits of grant 2017SGR1344 awarded by the Agència de Gestió d'Ajuts Universitaris i de Recerca de la Generalitat de Catalunya, which served to support the activities of the research groups (SGR2017-2019).

Acknowledgments: We would like to thank Sílvia Gimeno, for her support in conducting the interviews, Marien González-Hidalgo, for reviewing and preparing the interviews, and Meritxell Alcañiz, for her help with the data. The authors also wish to thank the Diputació de Barcelona and BOSCAT for providing information about the owners' associations and we are indebted to all the forest owners who agreed to be interviewed and the technicians who helped us to communicate with the forest owners. We wish to thank Iain Robinson (SL-UB) for revising the English manuscript.

Conflicts of Interest: The authors declare no conflict of interest.

\section{References}

1. Lloret, F. La resposta de la vegetació al foc: La dinàmica de la comunitat vegetal. In Ecologia del Foc; Terradas, J., Ed.; Edicions Proa and CREAF: Barcelona, Spain, 1996; pp. 41-45.

2. Boada, M. Boscos de Catalunya. Història i Actualitat del Món Forestal; Brau Edicions: Barcelona, Spain, 2003; pp. 1-188.

3. Pausas, J.; Keeley, J. Burning Story: The Role of Fire in the History of Life. BioScience 2009, 59, 593-601. [CrossRef]

4. Keeley, J.; Bond, R.; Bradstock, R.; Pausas, J.; Rundel, P. Fire in Mediterranean climate ecosystemsA comparative overview. Isr. J. Ecol. Evol. 2012, 58, 123-135.

5. Thirgood, J. Man and the Mediterranean Forest: A History of Resource Depletion, 1st ed.; Academic Press Ltd.: London, UK, 1981; pp. 1-194.

6. Pyne, S.J. Vestal Fire. An Environmental History, Told Through Fire, of Europe and Europe's Encounter with the World; University of Washington Press: Washington, DC, USA, 1997; pp. 1-672.

7. Chergui, B.; Fahd, S.; Santos, X.; Pausas, J. Socioeconomic factors drive fire regime variability in the Mediterranean Basin. Ecosystems 2018, 21, 619-628. [CrossRef]

8. Seidl, R.; Schelhaas, M.J.; Lexer, M.J. Unravelling the drivers of intensifying forest disturbance regimes in Europe. Glob. Chang. Biol. 2011, 17, 2842-2852. [CrossRef]

9. Fernandes, P. Fire-smart management of forest landscapes in the Mediterranean basin under global change. Landsc. Urban Plan 2013, 110, 175-182. [CrossRef]

10. Ferreira-Leite, F.; Bento-Gonçalves, A.; Vieira, A.; da Vinha, L. Forest Fires in Portugal-brief characterization. In Wildland Fires: A Worldwide Reality; Bento-Gonçalves, A., Vieira, A., Eds.; Nova Science Publishers: New York, NY, USA, 2015; pp. 115-137.

11. Olarieta, J.R.; Rodriguez-Valle, F.L.; Tello, E. Preserving and destroying soils, transforming landscapes: Soils and land-use changes in the Valles County (Catalunya, Spain) 1853-2004. Land Use Policy 2008, 25, 474-484. [CrossRef] 
12. Papanastasis, V.P.; Arianoutsou, M.; Lyrintzis, G. Management of biotic resources in ancient Greece. In Proceedings of the 10th Mediterranean Ecosystems (MEDECOS) Conference 2004, Atenas, Greek, 25 April1 May 2004; pp. 1-11.

13. Carmel, Y.; Kadmon, R. Effects of grazing and topography on long-term vegetation changes in a Mediterranean ecosystem in Israel. Plant Ecol. 1999, 145, 243-254. [CrossRef]

14. Wittenberg, L.; Malkinson, D.; Beeri, O.; Halutzy, A.; Tesler, N. Spatial and temporal patterns of vegetation recovery following sequences of forest fires in a Mediterranean landscape, Mt. Carmel Israel. Catena 2007, 71, 76-83. [CrossRef]

15. Úbeda, X.; Sarricolea, P. Wildfires in Chile: A review. Glob. Planet Chang. 2016, 146, 152-161. [CrossRef]

16. Mundet, R.; Baiges, T.; Beltrán, M.; Torrell, A. Adapt Your Cork Oak Forests to Resist Forest Fires; CFC: Girona, Spain, 2018.

17. Chaskin, R.J. Resilience, community, and resilient communities: Conditioning contexts and collective action. Child Care Pract. 2008, 14, 65-74. [CrossRef]

18. Vila, J.; Rodríguez-Carreras, R.; Varga, D.; Ribas, A.; Úbeda, X.; Asperó, F.; Llausàs, A.; Outeiro, L. Stakeholders perceptions of landscape changes in the Mediterranean mountains of the north-eastern Iberian Peninsula. Land Degrad. Dev. 2016, 27, 1354-1365. [CrossRef]

19. Wilson, G.; Kelly, C.L.; Briassoulis, H.; Ferrara, A.; Quaranta, G.; Salvia, R.; Detsis, V.; Curfs, M.; Cerda, A.; El-Aich, A.; et al. Social memory and the resilience of communities affected by land degradation. Land Degrad. Dev. 2017, 28, 383-400. [CrossRef]

20. Islas, P.V.; Vergara, D.G. Perceived visual landscape changes in a fire prone environment: A multi-method approach. J. Environ. Psychol. 2012, 32, 144-157. [CrossRef]

21. Pereira, P.; Mierauskas, P.; Novara, A. Stakeholders' Perceptions about Fire Impacts on Lithuanian Protected Areas. Land Degrad. Dev. 2013, 27, 871-883. [CrossRef]

22. Kooistra, C.; Hall, T.E.; Paveglio, T.; Pickering, M. Understanding the Factors that Influence Perceptions of Post-Wildfire Landscape Recovery across 25 Wildfires in the Northwestern United States. Environ. Manag. 2018, 61, 85-102. [CrossRef]

23. Carroll, M.S.; Cohn, P.J.; Blatner, K.A. Private and tribal forest landowners and fire risk: A two-county case study in Washington State. Can. J. For. Res. 2004, 34, 2148-2158. [CrossRef]

24. Nielsen-Pincus, M.; Ribe, R.G.; Johnson, B.R. Spatially and socially segmenting private landowner motivations, properties, and management: A typology for the wildland urban interface. Landsc. Urban Plan 2015, 137, 1-12. [CrossRef]

25. Amacher, G.S.; Malik, A.S.; Haight, R.G. Reducing Social Losses from Forest Fires. Land Econ. 2006, 82, 367-383. [CrossRef]

26. Fischer, A.P.; Charnley, S. Risk and Cooperation: Managing Hazardous Fuel in Mixed Ownership Landscapes. Environ. Manag. 2012, 49, 1192-1207. [CrossRef]

27. Rodríguez-Carreras, R.; Úbeda, X.; Outeiro, L.; Asperó, F. Perceptions of social and environmental changes in a Mediterranean forest during the last 100 years: The Gavarres Massif. J. Environ. Manag. 2014, 138, 75-86. [CrossRef]

28. Jarrett, A.; Gan, J.; Johnson, C.; Munn, I.A. Landowner awareness and adoption of wildfire programs in the southern United States. J. For. 2009, 107, 113-118.

29. Blennow, K.; Persson, J.; Wallin, A.; Vareman, N.; Persson, E. Understanding risk in forest ecosystem services: Implications for effective risk management, communication and planning. Forestry 2014, 87, 219-228. [CrossRef]

30. Fischer, A.P.; Vance-Borland, K.; Jasny, L.; Grimm, K.E.; Charnley, S. A network approach to assessing social capacity for landscape planning: The case of fire-prone forests in Oregon, USA. Landsc. Urban Plan 2016, 147, 18-27. [CrossRef]

31. Paletto, A.; Balest, J.; de Meo, I.; Giacovelli, G.; Grilli, G. Power of forest Stakeholders in the participatory decision making process: A case study in Northern Italy. Acta Silv. Lign. Hung. 2016, 12, 9-22. [CrossRef]

32. McCaffrey, S. Community wildfire preparedness: A global state-of-the-knowledge summary of social science research. Curr. For. Rep. 2015, 1, 81-90. [CrossRef]

33. FAO; EFI; Forest Europe. State of Europe's Forests. In Proceedings of the Ministerial Conference on the Protection of Forests in Europe FOREST EUROPE Liaison Unit 2015, Madrid, Spain, 20-21 October 2015. 
34. Catalan Forest Observatory. Ownership and Planning Documents. Available online: http://www. observatoriforestal.cat/ (accessed on 30 August 2019).

35. Stephenson, C.; Handmer, J.; Betts, R. Estimating the economic, social and environmental impacts of wildfires in Australia. Environ. Hazards-UK 2013, 12, 93-111. [CrossRef]

36. Paveglio, T.; Brenkert-Smith, H.; Hall, T.; Smith, A.M. Understanding social impact from wildfires: Advancing means for assessment. Int. J. Wildland Fire 2015, 24, 212-224. [CrossRef]

37. Paveglio, T.; Kooistra, C.; Hall, T.; Pickering, T. Understanding the effect of large wildfires on residents' well-being: What factors influence wildfire impact? For. Sci. 2016, 62, 59-69. [CrossRef]

38. Plana, E.; Domínguez, G.; Sangrà, G. La problemàtica dels grans incendis forestals com a causa-efecte del desequilibri territorial al món rural. Aprenent de l'experiència de 1998. Eng. i Sostenibilitat I Congrés d'Enginyers en Lleng. Catalana 2002, 2, 49-67.

39. Rodríguez-Carreras, R. Els incendis forestals des d'una perspectiva antròpica (Wildfires from an anthropic perspective). Treb. Soc. Cat. Geog. 2011, 71-72, 137-160.

40. Plana, E. Grandes incendios forestales y desarrollo rural: El incendio de la Cataluña central de 1998. Rev. des Rur. Coop. Agr. 1999, 3, 163-174.

41. Folch, R. Sociologia dels incendis forestals. In Ecologia del Foc; Terrades, J., Ed.; Edicions Proa: Barcelona, Spain, 1996; pp. 1-270.

42. Folke, C.; Hahn, T.; Olsson, P.; Norberg, J. Adaptive governance of social-ecological systems. Annu. Rev. Environ. Resour. 2005, 30, 441-473. [CrossRef]

43. Fazey, I.; Fazey, J.A.; Fischer, J.; Sherren, K.; Warren, J.; Noss, R.; Dovers, S. Adaptive capacity and learning to learn as leverage for socialecological resilience. Front. Ecol. Environ. 2007, 5, 375-380. [CrossRef]

44. Reed, M.S.; Evely, A.C.; Cund Ill, G.; Fazey, I.; Glass, J.; Laing, A.; Newig, J.; Parrish, B.; Prell, C.; Raymond, C.; et al. What is social learning? Ecol. Soc. 2010, 15, r1. [CrossRef]

45. Ison, R.; Watson, D. Illuminating the possibilities for social learning in the management of Scotland's water. Ecol. Soc. 2007, 12, 21. [CrossRef]

46. Bandura, A. Teoría del Aprendizaje Social; Espasa-Calpe Universitaria: Madrid, Spain, 1982; pp. 1-279.

47. Tàbara, J.D. Acció Ambiental. Aprenentatge i participació vers la sostenibilitat; Editorial Grao: Mallorca, Spain, 1999; pp. 1-173.

48. Sempere, J.; Rodríguez-Carreras, R.; Torrents, J. El Paper dels Experts en els Moviments Ambientalistes de Catalunya; Fundació Jaume Bofill, Collecció Finestra Oberta: Barcelona, Spain, 2005; pp. 1-45.

49. Keen, M.; Brown, V.A.; Dyball, R. Social Learning in Environmental Management: Towards a Sustainable Future; Earthscan: London, UK, 2005; pp. 1-288.

50. Wals, A. Social Learning-Towards a Sustainable World; Wageningen Academic Publishers: Wageningen, The Netherlands, 2007; pp. 1-532.

51. Rist, S.; Chidambaranathan, M.; Escobar, C.; Wiesmann, U.; Zimmermann, A. Moving from sustainable management to sustainable governance of natural resources: The role of social learning process in rural India, Bolivia and Mali. J. Rural Stud. 2007, 23, 23-37. [CrossRef]

52. Dedeurwaerdere, T. Social learning as a basis for cooperative small-scale forest management. Small Scale For. 2009, 8, 193-209. [CrossRef]

53. Tàbara, J.D.; Pahl-Wostl, C. Sustainability learning in natural resource use and management. Ecol. Soc. 2007, 12, 3. [CrossRef]

54. Pahl-Wostl, C.; Mostert, E.; Tàbara, J.D. The growing importance of social learning in water resources management and sustainability science. Ecol. Soc. 2008, 13, 24. [CrossRef]

55. Mezirow, J. Contemporary Paradigms of Learning. Adult Educ. Quart. 1996, 46, 158-172. [CrossRef]

56. Sharpe, J. Understanding and unlocking transformative learning as a method for enabling behaviour change for adaptation and resilience to disaster threats. Int. J. Disast. Risk Red. 2016, 17, 213-219. [CrossRef]

57. O'Brien, K. Global environmental change III: Closing the gap between knowledge and action. Prog. Hum. Geog. 2013, 37, 587-596. [CrossRef]

58. Otero, I.; Nielsen, J. Coexisting with wildfire? Achievements and challenges for a radical socialecological transformation in Catalonia (Spain). Geoforum 2017, 85, 234-246. [CrossRef]

59. Berkes, F.; Folke, C. Linking Social and Ecological Systems. Management Practices and Social Mechanisms for Building Resilience; Cambridge University Press: Cambridge, UK, 1998; pp. 1-459. 
60. Birot, Y.; Rigolot, E. The need for strategy anticipating climate ... and other changes. In Living with Wildfire: What Science Can Tell Us; Birot, Y., Ed.; EFI Discussion Paper: Joensuu, Finland, 2009; pp. 75-78.

61. Rego, F.; Rigolot, E.; Fernandes, P.; Montiel, C.; Silva, J.S. Towards integrated Fire Management. Europ. For. Inst. Policy Brief 2010, 4, 1-14.

62. Weber, M. Conceptos Sociológicos Fundamentals; Alianza Editorial: Madrid, Spain, 2014; pp. 1-202.

63. González-Hidalgo, M.; Zografos, C. How sovereignty claims and "negative" emotions influence the process of subject-making: Evidence from a case of conflict over tree plantations from Southern Chile. Geoforum 2017, 78, 61-73. [CrossRef]

64. Ostrom, E. Governing the Commons: The Evolution of Institutions for Collective Action; Cambridge University Press: New York, NY, USA, 1990; pp. 1-395.

65. Ostrom, E.; Ahn, T.K. Una perspectiva del capital social desde las ciencias sociales: Capital social y acción colectiva. Rev. Mex. Soc. 2003, 65, 155-233. [CrossRef]

66. Coleman, J.S. Social capital in the creation of human capital. Am. J. Sociol. 1988, 94, 95-120. [CrossRef]

67. Pretty, J. Social capital and the collective management of resources. Science 2003, 302, 1912-1914. [CrossRef]

68. Górriz-Mifsud, E.; Secco, L.; Pisani, E. Exploring the interlinkages between governance and social capital: A dynamic model for forestry. For. Policy Econ. 2016, 65, 25-36. [CrossRef]

69. Walker, G.B.; Senecah, S.L.; Daniels, S.E. From the Forest to the River: Citizens' Views of Stakeholder Engagement. Hum. Ecol. Rev. 2006, 13, 193-202.

70. Walker, G.B. Public Participation as Participatory Communication in Environmental Policy Decision-Making: From concepts to structured conversations. Environ. Commun. 2007, 1, 99-110. [CrossRef]

71. Evely, A.C.; Pinard, M.; Reed, M.S.; Fazey, I. High levels of participation in conservation projects enhance learning. Conserv. Lett. 2011, 4, 116-126. [CrossRef]

72. Górriz-Mifsud, E.; Ola Donazar, L.; Montero Eseverri, E.; Marini Govigli, V. The challenges of coordinating forest owners for joint management. For. Policy Econ. 2019, 99, 100-109. [CrossRef]

73. Sundar, N. Unpacking the "Joint" in Joint Forest Management. Dev. Chang. 2000, 31, 255-279. [CrossRef]

74. Picos Martin, J.; Ambrosio Torrijos, Y. Small non-industrial forest owners' cooperation examples in Galicia (NW Spain). In Forest Operation Improvements in Farm Forests, Proceedings of the Joint FAO/ECE/ILO Committee on Forest Technology, Management and Training, Logarska Dolina, Slovenia, 9-14 September 2003; International Labour Organization: Logarska Dolina, Slovenia, 2003.

75. Kittredge, D.B. The cooperation of private forest owners on scales larger than one individual property: International examples and potential application in the United States. For. Policy Econ. 2005, 7, 671-688. [CrossRef]

76. Berlin, C.; Lidestav, G.; Holm, S. Values placed on forest property benefits by Swedish NIPF owners: Differences between members in forest owner associations and non-members. Small Scale For. 2006, 5, 83-96.

77. Finley, A.; Kittredge, D.J.; Stevens, T.; Schweik, C.; Dennis, D. Interest in cross-boundary cooperation: Identification of distinct types of private forest owners. For. Sci. 2006, 52, 10-22.

78. Mendes, A.M.S.C. Forest owners' organizations in Portugal: Are the infant going to survive? In Small-Scale Forestry and Rural Development: The Intersection of Ecosystems, Economics and Society. Proceedings of the IUFRO 3.08 Meeting, Galway, Ireland, 18-23 June 2006; Wall, E., Ed.; COFORD Council: Dublin, Ireland, 2006; pp. 289-304.

79. Glück, P.; Avdibegović, M.; Čabaravdić, A.; Nonić, D.; Petrović, N.; Posavec, S.; Stojanovska, M. The preconditions for the formation of private forest owners' interest associations in the 500 Western Balkan Region. For. Policy Econ. 2010, 12, 250-263. [CrossRef]

80. Kueper, A.M.; Sagor, E.S.; Becker, D.R. Learning from Landowners: Examining the Role of Peer Exchange in Private Landowner Outreach through Landowner Networks. Soc. Natur. Resour. 2013, 26, 912-930. [CrossRef]

81. Sarvasova, Z.; Zivojinovic, I.; Weiss, G.; Dobsinská, Z.; Dragoi, M.; Gál, J.; Jarský, V.; Mizaraite, D.; Põllumäe, P.; Sálka, J.; et al. Forest owners associations in the Central and Eastern European Region. Small Scale For. 2015, 14, 217-232. [CrossRef]

82. Canadas, M.J.; Novais, A.; Marques, M. Wildfires, forest management and landowners' collective action: A comparative approach at the local level. Land Use Policy 2016, 56, 179-188. [CrossRef]

83. Kronholm, T. How are Swedish forest owners associations adapting to the needs of current and future members and their organizations? Small Scale For. 2016, 15, 413-432. [CrossRef] 
84. Sálka, J.; Dobsinská, Z.; Hricová, Z. Factors of political power-The example of forest owners associations in Slovakia. For. Policy Econ. 2016, 68, 88-98. [CrossRef]

85. Navascues, P.; Llobet, S. La gestión de montes privados en Regeneración a través de asociaciones de Propietarios forestales. Cuad. Soc. Esp. Cienc. For. 2007, 21, 61-66.

86. Kolb, D.A. Experiential Learning: Experience as the Source of Learning and Development; Prentice-Hall: Upper Saddle River, NJ, USA, 1984; pp. 1-41.

87. Mezirow, J. Learning to think like an adult: Core concepts of transformative theory. In Learning as Transformation; Mezirow, J., Ed.; Jossey-Bass: San Francisco, CA, USA, 2000; pp. 3-34.

88. Mezirow, J. Transformative learning theory. In Transformative Learning in Practice: Insights from Community, Workplace, and Higher Education; Mezirow, J., Ed.; Jossey-Bass: San Francisco, CA, USA, 2009; pp. 18-32.

89. Fazey, I. Resilience and higher order thinking. Ecol. Soc. 2010, 15, 9. [CrossRef]

90. Homer-Dixon, T. The Upside of Down-Catastrophe, Creativity and the Re-Newal of Civilisation; Souvenir Press: London, UK, 2006; pp. 1-429.

91. Nonaka, I.; Takeuchi, H. The Knowledge-Creating Company; Oxford University Press: Oxford, UK, 1995; pp. 1-284.

92. Armitage, D.; Marschke, M.; Plummer, R. Adaptive co-management and the paradox of learning. Glob. Environ. Chang. 2008, 18, 86-98. [CrossRef]

93. Waltz, A.E.M.; Stoddard, M.T.; Kalies, E.L.; Springer, J.D.; Huffman, D.W.; Meador, A.S. Effectiveness of fuel reduction treatments: Assessing metrics of forest resiliency and wildfire severity after the Wallow Fire, AZ. For. Ecol. Manag. 2014, 334, 43-52. [CrossRef]

94. Richardson, T.R.; Johanningmeir, E.V. Race, Ethnicity and Education: What is Taught in Schools; IAP, Information Age Pub: Charlotte, NC, USA, 2003; pp. 1-327.

95. Hollander, J.A.; Einwohner, R.L. Conceptualizing resistance. Sociol. Forum 2004, 19, 533-554. [CrossRef]

96. Giddens, A. Studies in Social and Political Theory (RLE Social Theory); Routledge: London, UK, 2014; pp. 1-420.

97. Taylor, S.J.; Bogdan, R. Introducción a los Métodos Cualitativos de Investigación; Editorial Paidós: Barcelona, Spain, 1987; pp. 1-344.

98. Merton, R.K.; Kendall, P.L. The Focused Interview. Am. J. Sociol. 1946, 51, 541-557. [CrossRef]

99. Weiss, R. Learning from Strangers: The Art and Method of Qualitative Interview Studies; The Free Press: New York, NY, USA, 1995; p. 256.

100. Valles, M.S. Entrevistas Cualitativas, 2nd ed.; CIS: Madrid, Spain, 2014; pp. 1-248.

101. Panareda, J.; Arola, J. Els Incendis Forestals; Eumo Editorial: Barcelona, Spain, 1999; pp. 1-136.

102. Forest Property Centre of Catalonia. Estructura de la Propietat Forestal a Catalunya, 2012. An\%\#xE0;lisi de les dades cadastrals. Generalitat de Catalunya. Available online: http://cpf.gencat.cat/web/.content/or_ organismes/or04_centre_propietat_forestal/01_organisme/publicacions/publicacions_tecniques/manuals/ manual_estructura_de_la_propietat_forestal_de_catalunya/cadastre.pdf (accessed on 30 August 2019).

103. Domínguez, G. Understanding Forest Owners in a Mediterranean Context. Constructing Theory through Descriptive and Interpretational Analysis. A Study Case in Catalonia. Ph.D. Thesis, Faculty of Forest and Environmental Sciences, Albert-Ludwigs-Universität Freiburg, Breisgau, Germany, April 2008.

104. Paton, D. Disaster preparedness: A social-cognitive perspective. Disaster Prev. Manag. 2003, 12, $210-216$. [CrossRef]

105. Castellnou, M.; Rodríguez, L.; Miralles, M. Replantejar-se el futur de la prevenció i extinció d'incendis forestals. In Incendis Forestals; Dimensió Socioambiental, Gestió del Risc i Ecologia del Foc: Solsona, Spain, 2004; pp. 44-49, Xarxa ALINFO XCT2001-00061.DL: L-501/2004.

106. Davis, L.S. The Economics of Wildfire Protection with Emphasis on Fuel Break Systems; California Division of Forestry: Sacramento, CA, USA, 1965; pp. 1-166.

107. Agee, J.; Bahro, B.; Finney, M.; Omi, P.; Sapsis, D.; Skinner, C.; Wagtendonk, J.; Weatherspoon, P. The use of shaded fuelbreaks in landscape fire management. For. Ecol. Manag. 2000, 127, 55-66. [CrossRef]

108. Costa, P.; Castellnou, M.; Larrañaga, A.; Miralles, M.; Kraus, D. La Prevención de los Grandes Incendios Forestales Adaptada al Incendio Tipo; Unitat Tècnica del GRAF, Departament d'Interior, Generalitat de Catalunya: Barcelona, Spain, 2011; pp. 1-87. 
109. Piqué, M.; Castellnou, M.; Valor, T.; Pagés, J.; Larrañaga, A.; Miralles, M.; Cervera, T. Integració del Risc de Grans Incendis Forestals (GIF) en la Gestió Forestal: Incendis Tipus i Vulnerabilitat de les Estructures Forestals al Foc de Capçades; Centre de la Propietat Forestal, Departament d'Agricultura, Ramaderia, Pesca, Alimentació i Medi Natural, Generalitat de Catalunya: Barcelona, Spain, 2011; pp. 1-130.

110. Keeley, J.; Pausas, J. Distinguishing disturbance from perturbations in fire-prone ecosystems. Int. J. Wildland Fire 2019, 28, 282-287. [CrossRef]

111. Cooper, C. Changes in vegetation, structure, and growth of south-western pine forests since white settlement. Ecol. Monog. 1960, 30, 130-164. [CrossRef]

112. Dodge, M. Forest fuel accumulation-a growing problem. Science 1972, 177, 139-142. [CrossRef]

113. Rothermel, R. Predicting behavior and size of crown fires in the Northern Rocky Mountains. Res. Pap. 1991, 438, 1-52.

114. Bilgili, E. Stand development and fire behavior. For. Ecol. Manag. 2003, 179, 333-339. [CrossRef]

115. Piatek, K.; McGill, D. Perceptions of Private Forest Owners in West Virginia on the Use of Prescribed Fire in Forestry. Small Scale For. 2010, 9, 227-241. [CrossRef]

116. Kreuter, U.P.; Woodard, J.B.; Taylor, C.A.; Teague, W.R. Perceptions of Texas Landowners regarding Fire and Its Use. Rangel. Ecol. Manag. 2008, 61, 456-464. [CrossRef]

117. Diputació de Barcelona. Modelos Silvícolas en Montes Privados Mediterráneos; Colección Documentos de Trabajo, Serie Territorio; Xarxa Audiovisual Local: Barcelona, Spain, 2008; pp. 1-113.

118. Guixé, D.; Sort, F.; Vilaseca, M. Territori de Masies. Paisatges, Biodiversitat i Món Rural al Baix Solsonès; L'Arada: Barcelona, Spain, 2014; pp. 1-250.

119. Bolòs, O.; Nuet, J.; Panareda, J.M. L'Estudi de la Vegetació de Catalunya, Passat, Present i Future; Editorial Montblanc-Martín: Barcelona, Spain, 1994; pp. 1-141.

120. González-Hidalgo, M.; Otero, I.; Kallis, G. Seeing beyond the smoke: The political ecology of fire in Horta de Sant Joan (Catalonia). Environ. Plan. A 2014, 46, 1014-1031. [CrossRef]

(C) 2020 by the authors. Licensee MDPI, Basel, Switzerland. This article is an open access article distributed under the terms and conditions of the Creative Commons Attribution (CC BY) license (http://creativecommons.org/licenses/by/4.0/). 